\title{
A respecification and extension of DeLone and McLean model of IS success in the citizen-centric e-governance
}

\begin{abstract}
Citizen-centric e-governance is an emerging approach in the case of designing and implementing the e-governance systems with the specific focus on the effectiveness. Based on this perspective, the citizens' needs and values on e-governance have to be put first to make these systems effective. This study is an attempt to explore and propose the needs and values of citizens on the e-governance systems based on the determinants of information system (IS) success in the DeLone and McLean 2003 (D\&M 2003) model of IS success. After conducting a comprehensive literature review, this study proposed new determinants of e-governance success and the citizen-centric e-governance success model. This model can be considered as the respecified and extended model of D\&M 2003 model of IS success in the specific context of the citizen-centric e-governance systems.
\end{abstract}

Keyword: Citizen-centric perspective; DeLone and McLean IS success model; E-governance effectiveness; E-governance systems 